\title{
Tribute to an adventurous Indian sedimentologist: Sukomol Kumar Chanda (1932-1998)
}

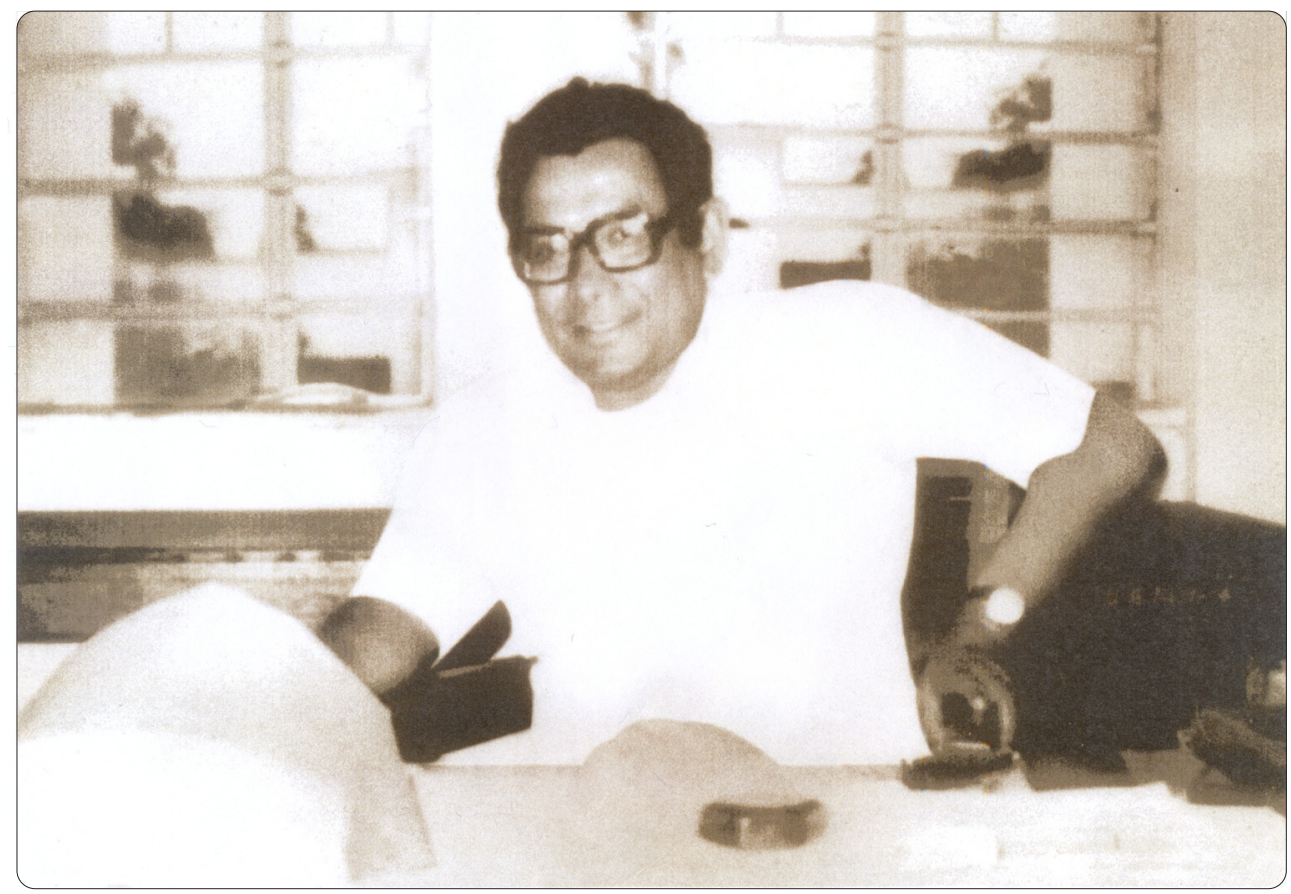

Professor Sukomol Kumar Chanda entered the area of teaching and research in sedimentology in the late fifties at the time of its infancy in India and shaped the course of its destiny and journey to maturity till the day he passed away prematurely on 10th July, 1998.

Sukomol was born on 8th October, 1932 into a modest family of strong East Bengalee stock in Dhaka, capital of the present Bangladesh. He was brought up in the tradition of a joint family with several brothers and sisters. He was the youngest son of the family. Sukomol had his schooling in the small, sleepy town of Digboi in Assam where his father was posted as a Railway official. He came to Kolkata to join the Asutosh College to do his graduation with honours in geology, and then did his Master's in geology in 1957 from the Jadavpur University.

Sukomol had a short stint with the Assam Oil Company just after he completed his Master's and the few months experience with the oil company played a crucial role in kindling his interest in sedimentology, a subject that was not accorded much importance by the Indian geoscientists of that time. He took sedimentology as the subject of his Ph.D. dissertation in the Jadavpur University, and most surprisingly the challenging field of carbonate sedimentology became the thrust area of his research. In the Jadavpur faculty, Sukomol was fortunate in having the close association of several brilliant researchers, his erstwhile teachers and class friends, which helped him to sharpen his research acumen and grow up as an academician. But without any peer guidance, he was a loner in his academic journey and successfully completed his Ph.D. dissertation in 1966 on the geology of the Mesozoic Lameta Group in Central India. Sukomol overcame the travails of the lonesome journey with modesty and gritty determination - traits that he inherited from his family and childhood upbringing as well as from an iconoclastic East Bengalee temperament. 
The late fifties and early sixties witnessed unprecedented development in the field of carbonate sedimentology, covering different aspects of carbonate particles and their petrogenesis, depositional systems, diagenesis and classification of carbonate rocks. The spurt of carbonate research was spearheaded by oil companies as well as a few centres in several universities in the USA, UK and Europe. Sukomol was greatly inspired by the works of Bob Folk at Austin, Texas and Robin Bathurst at Liverpool and actively participated with the global community of sedimentologists in their pursuits to unravel the mysteries of carbonate sedimentation, lithification and formation of carbonate rocks in the rock record. While so doing, he developed a close friendship with Bob Folk and Robin Bathurst, through correspondence and exchange of ideas. During this period he authored several papers on cementation and diagenesis of carbonate rocks (Chanda 1963, 1967a, 1967b, 1969, 1978). The contributions proved his mettle and acumen as a carbonate petrologist of international repute.

In the middle sixties, Sukomol developed for the first time his familiarity with the vast Proterozoic carbonate deposits in the Pranhita-Godavari Valley while supervising my doctoral dissertation. The Proterozoic sedimentary successions of India soon became his happy pasture and he extended his activities from the PG Valley to the Vindhyan basin. He made an outstanding contribution on compaction of carbonate sediments, and its bearing on the enigma of lithification of carbonate sediments in the mid-seventies while working on the Vindhyan limestones with his research students. Even up to the early seventies, subaerial exposure with diagenetic changes under the influence of meteoric water was thought to be the only process for lithification of carbonate sediments into limestones. The meteoric water paradigm was so firmly entrenched that it was even branded as "tyranny of fresh water only" by G M Friedman in 1975.

Though the correlation between lithification and exposure to meteoric water had been thoroughly substantiated for shallow water limestone sequences, the process had its serious drawbacks in explaining lithification in deep-water limestones. The application of meteoric water paradigm to deep water limestones would require "extraordinary sea level gymnastics that might even tax the imagination of most ardent advocates of subaerial cementation (Hopkins 1977)". At a time when carbonate sedimentologists were groping for a sustainable model for carbonate lithification beyond the influence of meteoric water, Sukomol came forward in concert with a few others with the hypothesis of compaction in deep water carbonate sediments as the major driving force for lithification and cementation of carbonate sediments into limestones (Hudson 1975; Chanda et al 1977; Shinn et al 1977; Scholle 1977). The studies on compaction rapidly changed the concept of carbonate diagenesis. These established that mud-supported carbonate sediments may undergo autolithification through pressure solution and reprecipitation without the benefit of subaerial exposure, and that burial diagenesis, rather than subaerial diagenesis, is normal for carbonate sediments deposited away from nearshore areas (Chanda et al 1983).

Sukomol's interest in carbonate diagenesis was kindled by the Jura-Cretaceous carbonate rocks of the Lameta Group around Jabalpur, it was fuelled by the carbonate rocks of the Mesoproterozoic Pakhal Group of the PG Valley, and reached the acme with the Neoproterozoic Vindhyan carbonates. During this process of development in carbonate petrogenesis, Sukomol was also looking into the diagenesis of siliceous sediments and formation of chert with keen interest, as diagenetic pathways of the two were often interlinked. He made a detailed analysis of chert fabric, comparing it with the diagenetic fabric of neomorphosed micritic limestone (Mukhopadhyay and Chanda 1972), and then put forward the early diagenetic pre-compaction origin of chert nodules in the Bhandar Limestone of the Vindhyan Supergroup (Chanda et al 1976). The pre-compaction chert nodules in lime-mud played a crucial role in subsequent studies on compaction, by way of providing tell-tale evidence for compaction against rigid bodies (Chanda et al 1977; Sarkar et al 1982). This penchant for diagenesis of limestone and chert persisted till his last days, and he returned to his old love in the mid-nineties, after a long pause, when he spearheaded the studies on deep water dolomite in the Neoproterozoic limestone of the PG Valley (Mukhopadhyay et al 1999) and made a significant contribution on maturation and fabric development in the Penganga chert, a paper that was published posthumously. While working on the Penganga chert, he became interested in the enigmatic question of the origin of bedded chert in the Proterozoic, a time by when organisms with siliceous tests had not yet evolved. I was intimately associated with this work on chert, that was slowly taking shape through the maze of conflicting thought-processes and intense debates. We tried to address several hitherto unsolved aspects related to the origin of Proterozoic chert, nature of the starting phase of siliceous sediments, maturation pathway and the possible role of bacteria in silica secretion. From the analysis of soft-sediment deformation structures and fluid escape features in thinly laminated chert, we focussed on the concept of direct precipitation 
of a siliceous precursor on the sea floor, controlled essentially by inorganic or silica-organic matter reactions in the clastic-starved Penganga basin. It was a daunting task to prove the role of organisms in the precipitation of silica, and the challenge provoked Sukomol to look for evidence to substantiate this working hypothesis, and to address the points raised in peer reviews. This was in February-March 1998, but this effort of an inquisitive mind would be snuffed out by cruel death in July 1998, before the hypothesis was finally established.

Sukomol had an abiding interest in facies analysis, analysis of palaeoenvironments, palaeogeography and stratigraphy. He inspired his students and co-workers, including myself, to look into different aspects of sedimentary rocks, both laboratory-based and field-based, to develop a comprehensiveness of interpretation. This urge for comprehensiveness took him to far-flung areas of Vindyachal, Chattisgarh, Telengana, Maharashtra and Bastar which included thickly forested inaccessible terrains of central India with almost non-existent or with very primitive logistical facilities. His contributions along with his co-workers, students or grand-students focussed on many aspects, including identification of storm and tidal deposits in the Vindhyans, coastal sabkha halite pans, origin of glauconitic peloids, manganese deposits in the deep water carbonate ramp or classification and identification of Neoproterozoic succession in Peninsular India (Chaudhuri et al 1999), and an overview of the Proterozoic succession of the PG Valley as a prelude to detailed basin and palaeogeographic analysis (Chaudhuri and Chanda et al 1991).

Sukomol was equally at ease with teaching, and carved out a place for himself as a venerable teacher of sedimentology who had the rare ability to encourage and enthuse his students, both at the undergraduate and graduate level, to give of their best. He was respected by all, and was instrumental in developing the teaching of sedimentology in the Jadavpur University to a place of eminence comparable with the best in India and abroad. Almost always he was in tune with his students and always took great care to expose them to the developing concepts in sedimentology and physical stratigraphy. He was also a rare breed whose office in his department could become a daily meeting point for many of the faculty members to freshen their minds with a bout of intellectual "adda" or an informal interactive session. Sukomol was the sounding board for many.

Sukomol's contribution to sedimentology cannot be measured only by the number of his publications or by the number of Ph.D. students he supervised. His most significant contribution lies in grooming and inspiring a number of younger researchers in major centres of sedimentological research that include the Jadavpur University, the Geological Studies Unit, ISI, the Presidency College, Kolkata and the Delhi University. He achieved the unique distinction of developing a school through his infectious enthusiasm, dedication, daunting expectations and philosophy, a school that Prof. P Allen termed as "Chanda's School of Sedimentology" during his sabbatical tenure in the Jadavpur University.

I became a student of Sukomol in my undergraduate class in 1961. But my real contact with him started as a Ph.D. student in 1966 when I was a Research Fellow in the Indian Statistical Institute, and had been working on the Proterozoic sedimentary succession in the PG Valley. The relationship continued till the last day of his life, uninterrupted. We almost developed together. As I grew up, I gradually realised that his entire being reflected a genuine, genteel balance between intellect and accessibility, conviction and openness, ardency and restraint. That welcoming smile, the understated but well thought out opinions, and the willingness to understand differing perspectives would inevitably be there. I spent many a day with him on the craggy hills, in the forests and vast wilderness of sparsely populated valleys of the Godavari, Pranhita and Indravati River. We discussed the nitty-gritties of sedimentology ranging from sediment transport, deposition and diagenesis on the one hand, and environments, basinal analysis and tectonics on the other. We often differed and debated, almost endlessly, on the meaning of our observations, and he never allowed me to stop the debate. Truly, he would ask questions not to deflate but to inquire, to raise the debate to a higher level of understanding. Sukomol soon became my friend and philosopher, like he was to many of my fellow travellers. I drew intellectual inspiration from his unflinching faith in dedication and involvement, his sincerity and openness that had not waned to the slightest degree till his last days. The day I met him last in the nursing home in south Kolkata when he underwent a surgery, Sarbani, my Ph.D. student, whom Sukomol was grooming up like his own, was with me. Sukomol requested me to bring him the draft copy of one of Sarbani's manuscripts to work on. As his physical condition was improving, I promised to bring him the manuscript the next day. But that 'next day' never came. Early next morning I got the information that Sukomol had passed away the night before.

I am sure there would be others who would remember him in other ways. Because just as there is no one path, there is no one memory. We all 
salute your memory, mentor, friend, philosopher and guide.

\section{References}

Chanda S K 1963 Cementation and diagenesis of the Lameta Beds, Lametaghat, M.P. India; J. Sedim. Petrol. 33 127-137.

Chanda S K 1967a Petrogenesis of the calcareous constituents of the Lameta Group around Jabalpur, M.P., India; J. Sedim. Petrol. 37 425-437.

Chanda S K 1967b Selective neomorphism and fabric discontinuities in limestone; J. Sedim. Petrol. 37 688-690.

Chanda S K 1969 Calcilithite fragments versus extraclasts; a discussion; J. Sedim. Petrol. 39 1640-1641.

Chanda S K 1978 Limestone compaction: An enigma: Comment; Geology 6 198-199.

Chanda S K, Bhattacharya A and Sarkar S 1976 Early diagenetic chert nodules in Bhander Limestone, Maihar, Satna District, Madhya Pradesh, India; J. Geol. 84 213-224.

Chanda S K, Bhattacharya A and Sarkar S 1977 Deformation of ooids by compaction in the Precambrian Bhander Limestone, India; Bull. Geol. Soc. America $\mathbf{8 8}$ $1577-1588$

Chanda S K, Bhattacharya A and Sarkar S 1983 Compaction in Limestones: A reappraisal; J. Geol. Soc. India 24 73-92.

Chaudhuri A K and Chanda S K 1991 The Proterozoic basin of Pranhita-Godavari valley: An Overview; In:
Sedimentary basins of India: Tectonic Context, Tandon S K, Pant C C, Casshyap S B (eds), Ganodaya Prakashan, Nainital, p. 13-30.

Chaudhuri A K, Mukhopadhyay J, Patranabis Deb, Sarbani and Chanda S K 1999 The Neoproterozoic successions of Peninsular India; Gondwana Research 2 213-225.

Hudson J D 1975 Carbon isotopes and limestone cement; Geology 3 19-22.

Mukhopadhyay A and Chanda S K 1972 Silica diagenesis in the banded hematite jasper and bedded chert associated with Iron Ore Group of the Jamda Koira Valley; Sedim. Geol. 8 113-135.

Mukhopadhyay J, Chaudhari A K and Chanda S K 1996 Deep water dolomite from Proterozoic Penganga Groups, Adilabad, Andhra Pradesh, India; J. Sedim. Res. 66 230-233.

Mukhopadhyay J, Chaudhari A K and Chanda S K 1999 Fabric development in Proterozoic bedded chert, Penganga Group, Adilabad, India: Sedimentologic implications; J. Sedim. Res. 69 735-749.

Sarkar S, Chanda S K and Bhattacharya A 1982 Softsediment deformation fabric in the Precambrian Bhander oolite, Central India; J. Sed. Petrol. 52 95-107.

Scholle P S 1977 Chalk diagenesis and its relation to petroleum exploration - oil from chalks, a modern miracle. Amer. Assoc., Pet. Geol. Bull. 61 922-1009.

Shinn E A, Halley R B, Hudson J H and Lidz B H 1977 Limestone compaction - An enigma. Geology 5 21-24.

Asru K Chaudhuri 